\title{
Is there any relation between anthropometric indices and decrease in seminal parameters?
}

\author{
Há relação entre os índices antropométricos e o decréscimo dos parâmetros seminais?
}

\author{
Juliana Christofolini ${ }^{1}$, Raphael Augusto Saab de Almeida Barros ${ }^{1}$, Milton Ghirelli-Filho', \\ Denise Maria Christofolini ${ }^{1}$, Bianca Bianco ${ }^{1}$, Caio Parente Barbosa ${ }^{1}$
}

\begin{abstract}
Objective: To investigate the influence of anthropometric indices on seminal parameters. Methods: Men who underwent treatment for conjugal infertility during the period of October, 2011, to March, 2012, were randomly selected. Patients with any prior diseases related to sperm alterations were excluded. Patients were submitted to an anthropometric evaluation to obtain body mass index, and the seminal analysis was made through a spermogram. Two anthropometric methods of classification were used: body mass index (normal and altered) and abdominal circumference $1<94 \mathrm{~cm}$ and $>94 \mathrm{~cm})$. Data were analyzed by statistical tests. Results: The group with the altered body mass index presented lower volumes of ejaculated volume and a larger percentage of patients with abdominal circumference $<94 \mathrm{~cm}$ presented with progressive forms of spermatozoa below reference values. However, in the statistical tests, there was no significant difference. Conclusion: No significant difference was found in the sperm quality relative to the body mass index or abdominal circumference.
\end{abstract}

Keywords: Adiposity; Male infertility; Body mass index; Semen; Reproduction

\section{RESUMO}

Objetivo: Investigar a influência dos índices antropométricos em parâmetros seminais Métodos: Foram selecionados de maneira aleatória homens que procuraram tratamento para infertilidade conjugal durante o período de outubro de 2011 até março de 2012. Foram excluídos os pacientes com quaisquer doenças relacionadas a alterações espermáticas prévias. Os pacientes passaram por avaliação antropométrica para obtenção do índice de massa corporal, e a análise seminal foi feita por meio de espermograma. Foram utilizados dois métodos de classificação antropométrica: índice de massa corporal (normal e alterado) e circunferência abdominal
$(<94 \mathrm{~cm}$ e $>94 \mathrm{~cm})$. Os dados foram analisados por meio de teste estáticos. Resultados: 0 grupo com índice de massa corporal alterado apresentou menores valores de volume de ejaculado, e uma fração maior de pacientes com circunferência abdominal $<94 \mathrm{~cm}$ apresentou formas progressivas de espermatozoide abaixo dos valores de referência. No entanto, nos testes estatísticos, não houve diferença significativa. Conclusão: Não foi encontrada diferença significativa na qualidade espermática em relação ao índice de massa corporal ou à circunferência abdominal.

Descritores: Adiposidade; Infertilidade masculina; Índice de massa corporal; Sêmen; Reprodução

\section{INTRODUCTION}

Obesity is a severe health problem observed in the entire world. ${ }^{(1)}$ Approximately 1.6 billion adults (aged over 15 years) are classified as being overweight (body mass index - BMI - between 25 and $30 \mathrm{~kg} / \mathrm{m}^{2}$ ) and 400 million as obese $\left(\mathrm{BMI} \geq 30 \mathrm{~kg} / \mathrm{m}^{2}\right)$. $^{(1)}$ The weight of Brazilians has also been increasing over the last years. Data from the Research on Family Budgets (POF, acronym in Portuguese for Pesquisa de Orçamentos Familiares) applied by the Brazilian Institute of Geography and Statistics (IBGE) in a partnership with the Ministry of Health showed that during the period between 2008 and 2009, excess weight already affected half of Brazilians, regardless of gender.(2) Obesity is an important health risk factor and is associated with high morbidity and mortality, especially due to cardiovascular diseases $^{(3,4)}$ and diabetes. ${ }^{(5)}$ It is also associated with other diseases, such as cancer ${ }^{(6)}$ and non-communicable

\footnotetext{
Faculdade de Medicina do ABC, Santo André, SP, Brazil.

Corresponding author: Caio Parente Barbosa - Avenida Príncipe de Gales, 821, building CEPES, 2th floor - Príncipe de Gales - Zip code: $09060-650$ - Santo André, SP, Brazil - Phone: (55 11) 3501-1749 E-mail: caiopb@uol.com.br

Received on: Mar 4, 2013 - Accepted on: Nov 8, 2013

Conflict of interest: none.

DOI: 10.1590/\$1679-45082014A02781
} 
chronic diseases, such as osteoarthritis, ${ }^{(7)}$ liver and gall bladder diseases, ${ }^{(8)}$ sleep apnea, ${ }^{(9)}$ depression, ${ }^{(10)}$ and infertility. ${ }^{(11)}$

The consequences of obesity in female fertility have been widely studied, but studies in the male population are less frequent. ${ }^{(12)}$ It has been postulated that obese men have an increased risk of erectile dysfunction. ${ }^{(13)}$ It has also been proposed that overweight and obesity in men can lead to a drop in levels of sex hormone-binding globulin (SHBG), increasing the levels of estradiol and altering secretion of gonadotropins. ${ }^{(14,15)}$

A significant reduction of testosterone levels relative to the serum levels of estradiol was observed in men with excess weight or obesity $\left(\mathrm{BMI}>25 \mathrm{~kg} / \mathrm{m}^{2}\right)$ when compared to the serum levels of men with a lower $\mathrm{BMI}^{(15)}$. This variation would be associated with the accumulation of adipose tissue, ${ }^{(15,16)}$ and the consequent hormone variation that can lead to oligozoospermia. More recently, it has also been described that overweight and obesity are related to lower levels of inhibin $\mathrm{B},{ }^{(17,18)}$ a marker of Sertoli cell function and spermatogenesis. Additionally, some studies have investigated if the excess weight affects the integrity of DNA of the sperm, ${ }^{(19)}$ as this is an independent marker of seminal quality ${ }^{(20)}$ that predicts fertility. ${ }^{(21,22)}$

Also reported was a higher prevalence of oligozoospermia in men with overweight/obesity relative to men with an appropriate weight. Nevertheless, no relation was found between the increase in BMI and the percentage of mobile sperm. . $^{(23)}$

Other authors reported a negative correlation between obesity and various seminal parameters in the general population. Nonetheless, there is controversy as to the extent of this relation. ${ }^{(23-25)}$

\section{OBJECTIVE}

To investigate the influence of body mass index and abdominal circumference on seminal parameters.

\section{METHODS}

Male patients were invited to participate in the study among couples with reproductive difficulties that searched/underwent treatment for infertility at the Instituto Ideia Fértil de Saúde Reprodutiva do Centro de Reprodução Humana e Genética da Faculdade de Medicina do $A B C$, recruited in a consecutive manner during the period between October, 2011 and March, 2012. Patients with varicocele, cryptorchidism, hypospadia, trauma, vasectomy reversal, and chromosome alterations and/ or micro deletion of the $\mathrm{Y}$ chromosome were excluded from the study.

Clinical and anthropometric data were only collected after presenting the objectives of the study and signing of the Informed Consent Form, approved by the Research Ethics Committee of the Instituto de Saúde e Bem Estar da Mulher (ISBEM).

Therefore, 118 men were selected for evaluation of BMI and abdominal circumference. The mean age of the men was $35.59 \pm 7.47$ years, and for their partners, $34.03 \pm 5.39$ years. The mean time of infertility of the couples was $3.38 \pm 3$ years.

Ninety-three individuals $(76.85 \%)$ declared not having any comorbidity and also no use of any type of medication. As to genital diseases or malformations, 105 $(86.77 \%)$ declared not having any disease/malformation. Of the patients who had any complaint, 5 cited sexually transmissible diseases $(4.14 \%)$ and the other 11 patients mentioned other diseases and malformations, such as inguinal hernias, hydrocele, and phimosis $(9.09 \%)$.

BMI was calculated as per the Quetelet formula, dividing the weight in kilograms by the squared height in meters: $\mathrm{BMI}=$ weight inkg/(height in $\mathrm{m})^{2}$.

To verify the influence of the anthropometric parameters on the variables of seminal analysis, participants were separated as per their nutritional status by their BMI, creating a control group $(18<\mathrm{BMI} \leq 25)$ and a study group (BMI $>25)$.

Taking into consideration that the BMl may have a bias relative to the patients that present with a high percentage of lean mass, who can be classified with $\mathrm{BMI}>25$, the abdominal circumference measurement was also used as a separation criterion of the participants in a second analysis. Therefore, two groups were obtained, one as control (abdominal circumference $<94 \mathrm{~cm}$ ) and one study group (abdominal circumference $\geq 94 \mathrm{~cm}$ ). The abdominal circumference was measured with an inelastic measuring tape at the level of the umbilical scar with volunteers in the orthostatic position.

For these groups, the spermogram was performed and evaluated in a timely fashion and according to the recommendations of the World Health Organization (WHO) in 2010. The cutoff values for sperm normality adopted for the variables were: volume $(\mathrm{V})>1.5 \mathrm{~mL}$; total concentration (TC) $>39$ million; initial concentration (IC) $>15$ million; progressive (PR) $>32 \%$ or progressive + non-progressive forms $(\mathrm{NP})=40 \%$.

Data analysis was done with the Statistical Package for Social Sciences (SPSS) program, version 16.0. Student's $t$ test was used to compare among the variables and the $\chi^{2}$ test and Kruskal-Wallis's non-parametric test 
for qualitative variables with a statistical significance value established at $5 \%$ or $\mathrm{p}<0.05$.

\section{RESULTS}

The distribution of the number of patients according to the BMI is shown on table 1 . The mean weight of patients was $87.0 \pm 19.29 \mathrm{~kg}$, while the mean height was $1.75 \pm 0.074 \mathrm{~m}$.

Table 1. Distribution of the number of patients according to the body mass index

\begin{tabular}{lc}
\hline BMI & Number of patients (\%) \\
\hline$<25$ & $31(26.2)$ \\
$25 \leq \mathrm{BMI}<30$ & $56(47.7)$ \\
$30 \leq \mathrm{BMI}<35$ & $21(17.7)$ \\
$35 \leq \mathrm{BMI}<40$ & $5(4.2)$ \\
$\geq 40$ & $5(4.2)$ \\
\hline Total & $118(100)$ \\
\hline BMl: body mass index. &
\end{tabular}

The abdominal circumference had a mean value of 96.42 and standard deviation of $\pm 13.99 \mathrm{~cm}$. Distribution of the number of patients, according to classes of abdominal circumference is demonstrated on table 2 .

Table 2. Distribution of the number of patients according to abdominal circumference

\begin{tabular}{lc}
\hline $\mathbf{A C}(\mathbf{c m})$ & Number of patients $(\%)$ \\
\hline$<94$ & $54(45.7)$ \\
$\geq 94$ and $<102$ & $30(25.4)$ \\
$\geq 102$ & $34(28.8)$ \\
\hline Total & $118(100)$ \\
\hline AC: abdominal circumference. &
\end{tabular}

In the seminal analysis, the variables observed were $\mathrm{V}$, TC, IC, and final concentration (FC), as well as the mobile and immobile forms of sperm.

Comparisons of the results of the seminal analysis among the groups of BMI and abdominal circumference are on table 3. The qualitative analysis between the groups showed no statistical difference in the results found, and the results of $\mathrm{p}$ value for the V versus BMI, and $\mathrm{V}$ relative to abdominal circumference ratios were 0.462 and 0.548 , respectively. For TC of sperm relative to the BMI, TC versus abdominal circumference, the $\mathrm{p}$ values were 0.932 and 0.378 . As to IC and BMI, the IC and abdominal circumference were 0.297 and 0.833 , respectively. The $\mathrm{p}$ values found for PR relative to the BMI, PR and the abdominal circumference were 0.875 and 0.169 , respectively.
Table 3. Comparison of the seminal values of patients below reference values as per body mass index and abdominal circumference values

\begin{tabular}{|c|c|c|c|c|c|c|}
\hline Variables & $\begin{array}{l}\text { Patients } \\
\text { with } \\
\text { BMI > 25 }\end{array}$ & $\begin{array}{l}\text { Patients } \\
\text { with } \\
\text { BMI } \leq 25\end{array}$ & $\begin{array}{c}\mathbf{p} \\
\text { value }\end{array}$ & $\begin{array}{c}\text { Patients } \\
\text { with } \\
\text { AC }>94\end{array}$ & $\begin{array}{c}\text { Patients } \\
\text { com } \\
\text { AC }<94\end{array}$ & $\underset{\text { value }}{p}$ \\
\hline $\begin{array}{l}\text { Volume } \\
<1.5 \mathrm{~mL}\end{array}$ & $\begin{array}{c}14.94 \% \\
\text { (n 13) }\end{array}$ & $\begin{array}{c}9.68 \% \\
\text { (n 3) }\end{array}$ & 0.462 & $\begin{array}{c}12.50 \% \\
\ln 8)\end{array}$ & $\begin{array}{c}16.36 \% \\
\text { (n 9) }\end{array}$ & 0.548 \\
\hline $\begin{array}{l}\text { TC }<39 \\
\text { million }\end{array}$ & $\begin{array}{c}21.84 \% \\
\text { (n 19) }\end{array}$ & $\begin{array}{c}22.58 \% \\
\ln 7)\end{array}$ & 0.932 & $\begin{array}{c}18.75 \% \\
\text { (n 12) }\end{array}$ & $\begin{array}{c}25.45 \% \\
\text { (n 14) }\end{array}$ & 0.378 \\
\hline $\begin{array}{l}\text { IC }<15 \\
\text { million }\end{array}$ & $\begin{array}{c}25.29 \% \\
\text { (n 22) }\end{array}$ & $\begin{array}{c}16.13 \% \\
\text { (5) }\end{array}$ & 0.297 & $\begin{array}{c}23.44 \% \\
\text { (n 15) }\end{array}$ & $\begin{array}{c}21.82 \% \\
(12)\end{array}$ & 0.833 \\
\hline $\begin{array}{l}\text { PR initial } \\
<32 \%\end{array}$ & $\begin{array}{c}14.94 \% \\
\text { (n 13) }\end{array}$ & $\begin{array}{c}16.13 \% \\
\ln 5)\end{array}$ & 0.875 & $\begin{array}{c}10.94 \% \\
\text { (n 17) }\end{array}$ & $\begin{array}{c}20.00 \% \\
(11)\end{array}$ & 0.169 \\
\hline
\end{tabular}

TC: concentration total; IC: initial concentration; PR: progressive sperm forms; BMI: body mass index; AC: abdominal circumference.

\section{DISCUSSION}

Male obesity has been the target of great discussion as to its impact on fertility, with much controversy in literature.

In the present paper, no statistical differences were found in the data analyzed between the BMI and abdominal circumference groups that would allow relating the drop in seminal quality of men with excess weight and/or obesity. Our results are similar to those of other larger studies, such as by Chavarro et al., ${ }^{(26)}$ who studied 483 men, members of infertile couples, and also found no significant differences between obese and eutrophic men as to sperm concentration and their motility, despite finding a greater $\mathrm{V}$ of ejaculation in non-obese men. Similarly, Jessen et al., ${ }^{(18)}$ in their study with 1558 Danish men, also found no significant differences between the total number of mobile sperm and the ejaculated $\mathrm{V}$, but did show, however, a reduction in concentration and in total sperm count in the group of men with a lower BMI $\left(<20 \mathrm{~kg} / \mathrm{m}^{2}\right)$. On the other hand, other studies, showed that obesity leads to alterations in almost all seminal parameters, such as ejaculated $\mathrm{V}$, and mobile and progressive forms of sperm. ${ }^{(27,28)}$

In the present study, we also found no significant difference when analyzing the abdominal circumference and the seminal parameters, contrasting with the findings of Fejes et al., ${ }^{(29)}$ who noted in their study an association between increased adiposity and a drop in sperm motility. Nevertheless, we cannot disregard the fact that the size of our sample influenced our results. Corroborating our findings, Strain et al. ${ }^{(30)}$ found no alterations in the $\mathrm{V}$ ejaculated and in motility of the sperm, verifying as well that the total count of sperm and libido were not altered with increased obesity, suggesting that this picture of hypogonadotropic hypogonadism is mild. 
Although our data support the statement that obesity does not lead to considerable changes in seminal parameters, there seem to be alterations in the fecundity of obese men. In our study, $87 \%$ of the participants were overweight or obese, while in another study, ${ }^{(26)}$ also performed in an infertility treatment clinic, $75 \%$ of the men were above ideal weight. Contrary to the still inconsistent findings regarding the influence of the BMI on the seminal parameters, there is a relation between excess weight and hormone parameters. ${ }^{(24,26,31-34)}$ Adding these findings to hormone alterations that demonstrate dysfunction of the seminiferous tubules and hypogonadotropic hypogonadism, we can support the hypothesis that obesity is a risk factor for a drop in fecundity and that, along with other mild risk factors, such as decreased libido and/or changes in sexual performance, may lead to infertility. ${ }^{(24)}$

\section{CONCLUSION}

The present study found no statistical difference between the body mass index and abdominal circumference and the drop in seminal quality of men with excess weight and/or obesity.

\section{REFERENCES}

1. Stothard KJ, Tennant PW, Bell R, Rankin J. Maternal overweight and obesity and the risk of congenital anomalies: a systematic review and meta-analysis. JAMA. 2009;301(6):636-50.

2. Instituto Brasileiro de Geografia e Estatística (IBGE). POF 2008-2009: desnutrição cai e peso das crianças brasileiras ultrapassa padrão internacional [Internet]. Brasília (DF); 2010. [citado em 2013 Nov 8]. Disponível em: http:// saladeimprensa.ibge.gov.br/noticias?view $=$ noticiagid $=1$ \&busca $=1$ gidnotic ia $=1699$

3. Must A, Spadano J, Coakley EH, Field AE, Colditz G, Dietz WH. The disease burden associated with overweight and obsesity. JAMA.1999:282(16):1523-9.

4. Klein S, Burke LE, Bray GA, Blair S, Allison DB, Pi-Sunyer X, et al. American Heart Association Council on Nutrition, Physical Activity, and Metabolism. Clinical implications of obesity with specific focus on cardiovascular disease: a statement for professionals from the American Heart Association Council on Nutrition, Physical Activity, and Metabolism: endorsed by the American College of Cardiology Foundation. Circulation. 2004;110(18):2952-67.

5. Coldtiz GA, Willet WC, Rotnitzky A, Manson JE. Weight gain as a risk factor for clinical diabetes mellitus in women. Ann Intern Med. 1995;122(7):481-6.

6. Calle EE, Rodriguez C, Walker-Thurmond K, Thun MJ. Overweight, obesity, and mortality from cancer in a prospectively studied cohort of U.S. adults. N Engl J Med. 2003;348(17):1625-38.

7. Reijman M, Pols HA, Bergink AP, Hazes JM, Belo JN, Lievense AM, et al. Body mass index associated with onset and progression of osteoarthritis of the knee but not of the hip: the Rotterdam Study. Ann Rheum Dis. 2007;66(2):158-62.

8. Tarher G, Arcaro G. Non-alcoholic fatty liver disease and increased risk of cardiovascular disease.Atherosclerosis.2007;191(2):235-40.

9. Pillar G, Shehadh N. Abdominal fat and sleep apnea: the chicken or the egg? Diabetes Care. 2008:31 (2 Suppl): S303-S9.
10. Petry NM, Barry D, Pietrzak RH, Wagner JA. Overweight and obesity are associated with psychiatric disorders: results from the National Epidemiologic Survey on Alcohol and Related Conditions. Psychosom Med. 2008:70(3):288-97.

11. Linné $Y$, Dye $L$, Barkeling $B$, Rössner $S$. Weigth development over time in parous women-- the SPAWN study--15 years follow-up. Int J Obes Relat Metab Disord. 2003;27(12):1516-22.

12. Wilborn C, Beckham J, Campbell B, Harvey T, Galbreath M, La Bounty P, et al. Obesity: prevalence, theories, medical consequences, management and research directions. J Int Soc Sports Nutr. 2005;2(2):4-31.

13. Bacon CG, Mittleman MA, Kawachi I, Giovannucci E, Glasser DB, Rimm EB. A prospective study of risk factors for erectile dysfunction. J Urol. 2006;176(1):217-21.

14. Pasquali R. Obesity and androgens: facts and perspectives. Fertil Steril. 2006;85(5):1319-40.

15. Hammoud AO, Gibson M, Peterson CM, Hamilton BD, Carrell DT. Obesity and male reproductive potential. J Androl. 2006;27(5):619-26.

16. Cin DD, Yuan W, Zhou WJ, Cui YQ, Wu JQ, Gao ES. Do reproductive hormones explain the association between body mass index and semen quality? Asian J Androl. 2007;9(6):827-34.

17. Berga SI, Yen SS. Reproductive failure due to central nervous systemhypothalamic pituitary dysfunction. In: Straus JF III, Baribieri RL, editors. Yen and Jaffe's reproductive endocrinology. Philadelphia: Elsevier; 2004 p.537-632

18. Jensen TK, Andersson AM, Jorgensen N, Andersen AG, Carlsen E, Petersen $\mathrm{JH}$, et al. Body mass index in relation to semen quality and reproductive hormones among 1,558 Danish men. Fertil Steril. 2004;82(4):863-70.

19. Kort HI, Massey JB, Elsner CW, Mitchell-Leef D, Shapiro DB, Witt MA, et al. Impact of body mass index values on sperm quantity and quality. J Androl. 2006;27(3):450-2.

20. Trisini AT, Singh NP, Duty SM, Hauser R. Relationship between human semen parameters and deoxyribonucleic acid damage assessed by the neutral comet assay. Fertil Steril. 2004;82(6):1623-32.

21. Spanò M, Bonde JP, Hjollund HI, Kolstad HA, Cordelli E, Leter G. Sperm chromatin damage impairs human fertility. Fertil Steril. 2007;73(1):43-50.

22. Chan DC, Watts GF, Barrett PH, Burke V. Waist circumference, waist-to-hip ratio and body mass index as predictors of adipose tissue compartments in men. 0JM. 2003;96(6):441-7.

23. Ohwaki K, Endo F, Yano E. Relationship between body mass index and infertility in healthy male Japanese workers: a pilot study. Andrologia. 2009;41(2):100-4.

24. Pauli Em, Legro RS, Demers LM, Kunselman AR, Dodson WC, Lee PA. Diminished parternity and gonadal function with increasing obesity in men. Fertil Steril. 2008;90(2):346-51.

25. Sallmén M, Sandler DP, Hoppin JA, Blair A, Baird DD. Reduced fertility among overweight and obese men. Epidemiology. 2006;17(5):520-3.

26. Chavarro JE, Toth TL, Wright DL, Meeker JD, Hauser R. Body mass index in relation to semen quality, sperm DNA integrity, and serum reproductive hormone levels among men attending na infertility clinic. Fertil Steril. 2010;93(7):2222-31.

27. Nguyen RH, Wilcox AJ, Skjaerven R, Baird DD. Men's body mass index and infertility. Hum Reprod. 2007;22(9):2488-93.

28. Koloszár S, Fejes I, Závaczki Z, Daru J, Szöllosi J, Pál A. Effect of body weight on sperm concentration in normozoospermic males. Arch Androl. 2005;51(4):299-304.

29. Fejes I, Koloszár S, Szöllosi J, Závaczki Z, Pál A. Is semen quality affected by male body fat distribution? Andrologia. 2005;37(5):155-9.

30. Strain GW, Zumoff B, Kream J, Strain JJ, Deucher R, Rosenfeld RS, et al. Mild Hypogonadotropic hypogonadism in obese men. Metabolism. 1982;31(9):871-5.

31. Glass AR, Swerdloff RS, Bray GA, Dahms WT, Atkinson RL. Low serum 
testosterone and sex-hormone-binding-globulin in massively obese men. $J$ Clin Endocrinol Metab. 1977;45(6):1211-9.

32. Schneider G, Kirschner MA, Berkowitz R, Ertel NH. Increased estrogen production in obese men. J Clin Endocrinol Metab. 197;48(4):633-8.
33. Meachem SJ, Nieschlag E, Simoni M. Inhibin B in male reproduction: pathophysiology and clinical relevance. Eur J Endocrinol. 2001;145(5):561-71.

34. Pierik FH, Burdorf A, de Jong FH, Weber RF. Inhibin B: a novel marker of spermatogenesis. Ann Med. 2003;35(1):12-20. 